\title{
KOGNITÍV KÉPESSÉGEK INFORMATIKAI ALAPÚ FEJLESZTÉSÉNEK HATÁSVIZSGÁLATA 5-8. ÉVFOLYAMON TANULÓK KÖRÉBEN
}

\author{
Szerző: \\ Szabóné Balogh Ágota \\ Gál Ferenc Egyetem \\ (Magyarország)
}

Szerző e-mail címe:

szabone.balogh.agota@gfe.hu

\section{Lektorok:}

Mező Katalin (Ph.D.)

Debreceni Egyetem

(Magyarország)

Mező Ferenc (Ph.D.)

Eszterházy Károly Egyetem

(Magyarország)

és további két anonim lektor...

\section{Absztrakt}

Jelen tanulmány célja az informatika alapú kognitív képességfejlesztés (figyelem, emlékezet, gondolkodás) hatékonyságának vizsgálata az általános iskola felső tagozatában. A vizsgálat kiterjedt a kísérleti csoport hatásvizsgálatára, a mintaváltozók hatására az elô- és utóvizsgálatok eredményeire, a vizsgálati változók korrelációjára.

Kulcsszavak: képesség, fejlesztés, informatika

Diszciplína: pedagógia, pszichológia

\section{Abstract}

EFFECTIVENESS STUDY OF IT-BASED DEVELOPMENT OF COGNITIVE ABILITIES OF 5th-8th GRADE STUDENTS

The aim of the study is to examine the efficiency of information technology - based development of cognitive abilities (attention, memory, cognition) in 5-8 grades of elementary school. The study also includes the effectiveness indexes of the experimental group, the effect of sample variables on the results of the pre-, and poststudies, and the correlation of study variables.

Keywords: ability, development, information technology

Disciplines: pedagogy, psychology

Szabóné Balogh Ágota (2020): Kognitív képességek informatikai alapú fejlesztésének hatásvizsgálata 5-8. évfolyamon tanulók körében. OxIPO - interdiszciplináris tudományos folyóirat, 2020/4, 41-58. doi: 10.35405/OXIPO.2020.4.41 
A magyar oktatási rendszer egyik fontos alapelve (lásd: 2011. évi CXC törvény a Nemzeti Köznevelésről), hogy az iskolákban a tanulók készségeinek és képességeinek a fejlesztése is megvalósuljon. Ezzel összefüggésben például országos és nemzetközi vizsgálatok (PISA, OKM) mérik a felső tagozatos és a középiskolás tanulók képességeit (Ostorics, 2015). A tanulók kognitív képességeinek vizsgálata hazai és nemzetközi szinten is sokat kutatott terület. A korai kutatások (például: Piaget, 1950; Spearman, 1927 és mások) mellett napjainkban is számos vizsgálat (például Adams és Gathercole, 2000; Hautamäki és társai, 2002; Csapó, 2003; Polonkai, 2004; Balogh, 2004; Hoskins és Fredrikson, 2008; Janacsek és társai, 2009; Gyarmathy, 2009; Kim és társai, 2010; Manches és társai, 2010; Habók, 2011; Molnár és Csapó, 2011; Sparrow és társai, 2011; Yang, 2012; Molnár, 2013; Debreczeni, 2013; Mező és Mezô, 2014; Mohai és Szabó, 2014; Tánczos és társai, 2014, Csapó és társai, 2015; Pásztor és Molnár, 2015; Dávid és társai, 2016; Mező, 2017) tűzi ki célul e képességek megismerését.

Az Európai Parlament és a Tanács (2006) célul tűzte ki az „egész életen át tartó" tanulást, a kompetenciaalapú oktatást. Ehhez nyolc kulcskompetenciát köztük a digitális kompetenciát - határozott meg, melyekhez szorosan kapcsolódik a képességek fejlesztése is. A kompetencia alapú oktatásban megjelenik a kognitív kompetencia fogalma (az információk vétele, tárolása, feldolgozása, közlése) és annak komponensrendszere (kognitív ismeretek, összetett és egyszerűbb kognitív képességek - rutinok, készségek - Tóth, 2010). Ezzel összefüggésben jelen tanulmány tárgyát - az informatika bevonását a képességfejlesztésbe az indokolja, hogy napjaink gyermekeit digitális nemzedéknek is szokás nevezni, más néven netgenerációnak (Tari, 2011). Ők azok, akik az informatikai lehetőségekkel, az internet sokoldalú felhasználásával együtt nőnek fel, mindennapjaikat meghatározza a digitális világ. Időszerűvé vált tehát a korszerű digitális technológia bevonása a netgeneráció képességeinek fejlesztésébe. Ezt a célt szem előtt tartva, az informatikai eszközök és a képességfejlesztés összekapcsolásának lehetőségét vizsgálva, Greenfield (2009) megállapította, hogy a vizuális figyelem, a párhuzamos feldolgozás képessége, a téri-vizuális kapacitás is fejlődik az internet használatával. Sung és társai (2008), Yang, (2012) a gondolkodási képességek fejlesztésére digitális, játék alapú hatékony fejlesztőprogramokat készítettek. Shaffer és társai (2004) szerint a számítógépes játékok hatására a tanulók problémamegoldása, gondolkodása fejlődik. Dávid és társai (2016) a téri memóriával kapcsolatos kutatása szerint a keveset számítógépező gyerekeknek gyengébb a teljesítménye. Jelen tanulmány ehhez a problémakörhöz kapcsolódik, vizsgálva a figyelem, emlékezet, gondolkodás fejleszthetőségét informatikai környezetben. 


\section{Kognitív fejlődés és fejleszthetőség}

A gyermekek születésüktől kezdve hosszú fejlődési folyamaton mennek keresztül testi, kognitív fejlődés, a személyiség és a társas kapcsolatok terén egyaránt. Freud (1933, 1964), Erikson (1963), Piaget (1969), Kohlberg (1976) egyaránt vizsgálták ezeket a folyamatokat, és a fejlődést szakaszokra bontották. A gyermekek kognitív fejlődését kezdetben az öröklés (biológiai) és a környezet (nevelés) oldaláról közelítették meg. Megállapították, hogy a fejlődés menete függ az éréstől, és a környezettel való kölcsönhatástól (Atkinson és tsai, 2001). A kognitív pszichológia vizsgálatainak meghatározó kutatója Jean Piaget (1969) megalkotta az egyik legelfogadottabb kognitív fejlődéselméleti modellt. A saját tapasztalatai alapján - lányai megfigyelése után - azt állapította meg, hogy az érést, a biológiai fejlődést és a környezeti hatásokat a gyermekek aktívan élik meg, fogadják be, s ezekből sémákat alkotnak (asszimiláció és akkomodáció révén Piaget és Inhelder, 1969). Piaget a természetes érő képesség és a környezet kapcsolatát, és azok kölcsönhatásait állította előtérbe (Turner, 1994).

Piaget (1950, 1969) fejlődéselméletében az életkorhoz kötve négy szakaszt különböztetett meg:

1. Az érzékszervi-mozgásos/szenzomotoros periódus: 0-2 éves kor. A gyermek a világot az érzékelés, az észlelés, a mozgás útján fedezi fel.
2. A művelet előtti szakasza: 2-7 éves kor. Ekkor alakul ki fokozatosan a megőrzés és decentrálás képessége. Még igazi logikai műveleteket nem végez a gyermek. Egocentrizmus, szinkretizmus jellemzi, a dimenziók közötti kapcsolatot nem érzékeli.

3. A konkrét múveletek szakasza: 7-11 éves kor. Ezt a szakaszt a decentrálás, a műveletek végzése, a konzerváció, a gondolkodás reverzibilitása jellemzi. A problémamegoldás konkrét tapasztalatok általánosításával történik. Képes több dimenzióra és azok kapcsolataira figyelni.

4. A formális műveletek szakasza: 11 éves kortól. Képes hipotézisalkotásra, szisztematikus, kombinatorikus, absztrakt gondolkodásra, és elvont műveletvégzésére.

Más megközelítések is léteztek, mint az információfeldolgozás. Ennek követői (köztük: Klahr, 1982; Mandler, 1983; Case, 1985) a kognitív fejlődést több különbözô információfeldolgozási készség elsajátításaként fogták fel. A tudásmegszerzési megközelítés követői (Chase és Simon, 1973; Chi, 1978, Keil, 1989) pedig úgy gondolták, hogy a csecsemő, a gyermek, a felnőtt ugyanazon kognitív folyamatokkal és képességekkel rendelkezik, de a felnőttek tudása kiterjedtebb, és mélyebb a megértésük is.

A kognitív képességek kutatásának története elválaszthatatlan az intelligenciakutatás történetétől. Az újkori intelli- 
genciakutatások kezdete Galton (1869) nevéhez füződik. A speciális képességekből (s-faktorok) adódó általános intelligencia ( $\mathrm{g}$-faktor) létezését Spearman (1904) vetette fel. Thurstone (1938) hét elsődleges mentális képességet különböztetett meg: verbális fluencia (szótalálás gyorsasága); verbális felfogás (nyelvi megértés); perceptuális sebesség; számolás; memória; indukció (általánosítás, következtetés); térbeli percepció.

A hierarchikus intelligencia modell Vernon (1950) nevéhez füződik, mely szerint a hierarchikus intelligencia csúcs, elsőrendű, másodrendű és speciális faktorokból áll. A modell csúcsán a gfaktor van, ami két elsőrendű faktorból verbális-edukációsból (másodrendű faktorai: verbális és számolási képesség, ezek alá speciális faktorok tartoznak) és a praktikus-mechanikusból áll (másodrendű faktorai: térbeli, mechanikus, pszichomotoros, ezek alá speciális faktorok tartoznak).

Guilford (1959) intelligencia struktúra („Structure of Intelligence”, SoI) modellje 5 művelet $\times 4$ tartalom $\times 6$ produktum $=$ 120 képességfaktort említ:

- mûveletek: megismerés, emlékezés, konvergens gondolkodás, divergens gondolkodás, értékelés,

- tartalmak: figurális, szimbolikus, szemantikus, viselkedéses

- produktumok: egység, osztály, viszony, rendszer, transzformáció, implikáció.
Cattell (1971) kétféle intelligenciát különböztet meg: a fluid intelligenciát (a problémamegoldás alapja), és a kikristályosodott intelligenciát (az ismeretek alkalmazásának alapja). Hebb (1975, 1997) szintén kétféle intelligenciát különít el: „A” (genetikailag determinált, nem mérhető) és „B” (a környezet hatására alakuló - így fejleszthető! -, mérhető) intelligenciát.

Gardner (1983, 1986) a többszörös intelligencia elméletében (kezdetben) hétféle intelligenciát különböztetett meg:

- nyelvi (szóbeli, beszéd, írás, olvasás)

- logikai-matematikai (matematika, absztrakt következtetések)

- téri-vizuális (téri tájékozódás, vizualitás)

- zenei,

- testi-kinesztetikus (kinetikus, mozgásos)

- interperszonális (személyközi, befolyásolás, együttmúködés)

- intraperszonális (személyen belüli, önismeret).

Mindezt később kiegészítette egy nyolcadikkal, a természeti intelligenciával.

Az összetevőkben mindenki elér egyfajta szintet, de azoknak a mértéke és a mintázata különbözik. Az utolsó négy összetevô általában hiányzik az intelligenciatesztekből. Az intelligencia fontos, mert az értelmi képességek azon rendszere, mely sikeressé teszi a megoldá- 
sokat és a környezethez való alkalmazkodást, de meghatározza a megismerési folyamatok által a képességrendszer belső szerkezetét is. Az intelligencia segítségével oldhatóak meg a problémák, küzdhetőek le a nehézségek. Szorosan összefügg az általános és speciális képességekkel, ezáltal meghatározza a teljesítményt. Megmutatja, hogy milyen mértékben alkalmazható a tudás, ami a tevékenység gyakorlatiasságában is megmutatkozik (Knausz, 2001; Estefánné és tsai, 2008).

Sternberg (1985) információfeldolgozási modelljében az intelligenciát többféle folyamat együttes működésével jellemzi. Az összetevők egyik csoportja a megismeréshez (tanulás, előhívás, átvitel) kapcsolódik, a másikat a gondolkodási összetevők alkotják (metaösszetevők által a gondolkodási folyamtok irányítása, összehangolása; teljesítmény összetevők gondolkodás végrehajtása). Sternberg (1985) szerint az intelligenciát meghatározza a tanulási képesség, az absztrakt gondolkodási képesség, a változó világhoz való alkalmazkodás, a megoldandó feladatok iránti motiváltság.

$\mathrm{Az}$ intelligencia vizsgálata szorosan kapcsolódik a mesterséges intelligencia (MI) kutatásához, melynek a fogalmát sokféleképpen értelmezik.

Russel és Norvig (2000, 34. o) az alábbi szerzőket idézi:

- „Az emberi gondolkodással asszociálható olyan aktivitások (automatizálása), mint pl. a döntéshozatal, a problémamegoldás, a tanulás," (Haugeland, 1985)

- „A mentális képességek tanulmányozása számítási modellek segítségével" (Charniak és McDermott, 1985)

- „A számítógépes tudományok egy ága, amely az intelligens viselkedés automatizálásával foglalkozik" (Luger és Stubblefield, 1993).

Alan Turing (1950) nevéhez füződik a „Turing-teszt”, melyben az intelligens viselkedést vizsgálja. Egy kérdező monitoron, billentyűzeten keresztül kérdezgeti a tesztalanyt, akinek el kell döntenie, hogy géppel vagy emberrel beszélget-e. Amennyiben azt szeretnénk, hogy a számítógépet embernek gondolják a teszt során, akkor annak a következő képességekkel kell rendelkeznie: természetes nyelvfeldolgozás, tudásreprezentáció, automatizált következtetés, gépi tanulás, gépi látás, robotika (Russel és Norvig, 2000). Mindezekhez ismerni kell, hogy az ember hogyan gondolkozik. Newell, Shaw és Simon $(1958,1961)$ egy ,általános problémamegoldó"-nak (General Problem Solver, GPS) nevezett modellt fejlesztettek ki. Nem csak azt vizsgálták, hogy az „alany” helyesen oldotta-e meg a problémát, hanem összehasonlították az ember és a gép lépéseit, melyeket a feladat megol-dása során tettek. (Nevell és Simon, 1961). Craik (1943) az inger és a válasz között mentális lépést is vizsgálta, 
megfogalmazta a tudásalapú ágens működésének fontos lépéseit.

A tanulásban legfontosabb képességegyüttest intelligenciának, értelmi képességnek, megismerő képességnek vagy kognitív képességnek is nevezik (Kelemen, 2014). Az alapvető intellektuális képességek (figyelem, emlékezet, gondolkodás) fejlesztését indirekt tanulásfejlesztésnek, a tanulási módszerek gyakoroltatását pedig direkt tanulásfejlesztésnek nevezik (Mező, 2011a). A tanulók értelmi képességeinek meghatározó szerepe van a tanulási teljesítményben, ezek fejlesztése is elengedhetetlen. Az iskolai tanulás eredményességét az intelligencián kívül a szorgalom, az érdeklődés, az ambíció, a céltudat stb. is befolyásolja. Ugyanakkor az intelligencia közvetve is befolyásolhatja az összefüggő tanulási teljesítményt (Báthory, 2000).

\section{Kognitív képességek}

\section{vizsgálata, mérése és fejlesztése}

Napjainkra az intelligencia, az intellektuális képességek mérésére többféle tesztet fejlesztettek már ki. Ilyen például a Raven-tesztcsalád, a „Budapest Binet” intelligenciateszt, a Goodenough-féle emberalak-ábrázolás vizsgálat, a WoodcockJohnson kognitív képességek tesztje, a KFT stb. (Katona, 2000; Mező, 2011, 2017). Gyarmathy (2009) „Kognitív Profil tesztje" online felületen (http://kognitivprofil.hu) is elérhető, s nemzetközi összehasonlító vizsgálatban használt teszt át- dolgozása, mely a kognitív képességeket, az információfeldolgozást, az iskolai készségeket vizsgálja.

Magyarországon több kutató illetve kutatócsoport is foglalkozik a kognitív képességek vizsgálatával, fejlesztésével. Például:

- A Debreceni Egyetem, PedagógiaiPszichológiai Tanszéke (Balogh, 2004; 2006) is folytatott vizsgálatokat a témában - komplex tehetséggondozó programok (1990-2000) keretében megvalósuló longitudinális vizsgálat (n=460) során. Megjegyzés: jelen tanulmány kutatási részében többnyire az említett vizsgálatban alkalmazott mérőeszközöket használjuk fel.

- Az általános intellektuális képességek vizsgálatára - az Arany János Tehetséggondozó Programban (AJTP) résztvevő több évfolyam tanulói esetében - a Debreceni Egyetem Pedagógiai-Pszichológiai Tanszékének munkatársai a KFT-teszt hétféle altesztjét alkalmazzák: szókincs, mondatkiegészítés, verbális osztályozás, verbális analógia, figuraosztályozás, számsor, figura analógia. Az első négy a verbális általános intellektuális képességeket méri, a másik három a nonverbálisat. A kutatás eredményeként megállapították, hogy induláskor az évfolyamok intellektuális képességek kiegyensúlyozottak voltak. Osztályonként már találtak eltéréseket. A verbális általános intellek- 
tuális képességek színvonala kiegyensúlyozottabb volt, mint a nem verbálisaké (Balogh, 2004.). Az AJTP nyomon követéses vizsgálatok 2000 óta folynak (Polonkai, 2004; Fehérvári és Liskó; 2006).

- A Monitor '95-ös vizsgálat során összefüggéseket vizsgáltak a kognitív képességek és tantárgyi tesztek között: a kognitív teszt korrelációt mutatott a matematikával és az olvasásmegértéssel, a számítástechnikával gyengén korrelált (Vári, 1997, Báthory, 2000).

- Dávid és társai (2014) az infokommunikációs eszközök használatának hatását vizsgálták.

- Farkas (2000) a játékos informatika hatékonyságát kutatta. Arra a következtetésre jutott, hogy az elsősök esetében a legsikeresebb ennek alkalmazása volt

- A Szegedi Tudományegyetem Oktatáselméleti kutatócsoportja is mérte az általános iskolás tanulók gondolkodását, figyelmét, emlékezetét. Ez a mérés online tesztelés volt (edia.hu), melyben az ország nagyon sok általános iskolája részt vett (Csapó és tsai, 2015; Pásztor és Molnár, 2015).

- A Magyar Képzőművészeti Egyetem (EFOP-3.2.6-16-2016-00001 azonosítószámú) projektje keretében a $\mathrm{K}+\mathrm{F}$ Stúdió Kft. által fejlesztett S.M.ART múvészeti foglalkozásokba ágyazható, az OxIPO-modellen alapuló diagnosztikai eszközrendszer sajátos képességhierarchia alapján teszi lehetővé a gyors, iskolai körülmények között jól alkalmazható vizsgálatokat (Mező, 2019).

\section{Vizsgálat}

Jelen kutatás célja megismerni, hogy milyen változást hoz a tanulók figyelmi, emlékezeti és gondolkodási képességeibe. egy folyamatos, négy tanéven át tartó informatikai, interaktív alapokon nyugvó képességfejlesztés. A kutatás során a tanulók széleskörű, több szempontú megismerése szempontjából sor kerül további vizsgálatokra is, mint például a háttértényezők (kreativitás, tanulási motiváció, tanulási orientáció) feltárására is.

\section{Minta}

A vizsgálati mintát 348 általános iskola felső tagozatába járó tanuló alkotta. A vizsgálati csoportban 174 tanuló vett részt 89 fiú és 85 lány, a kontrollcsoportban szintén 174 fő: 91 fiú, 83 lány. A longitudinális vizsgálat során a bemeneti mérés idején a tanulók 5. osztályosak (1011 évesek), a kimeneti mérésnél 8. osztályosak (14-15 évesek) voltak. A tanulók hét-hét vidéki település iskolájából kerültek ki, a mintavétel széleskörű, de nem reprezentatív. A korosztály választását indokolta: egyrészt az alsó tagozatból a felsô tagozatba való átmenet, a nagyobb követelmény megjelenése (nagyobb mennyiségű tananyag, új tantárgyak); másrészt a felső tagozatos 
tanulók már rendelkeznek olyan informatikai ismeretekkel, melyek szükségesek a számítógépes lehetőségek használatához. A szülők a vizsgálatról szóló tájékoztatáson vettek részt, majd írásbeli hozzájárulásukkal engedélyezték a tanulók vizsgálatban való részvételét. A vizsgálat kiterjed a vizsgálati csoport hatásvizsgálatára; a mintaváltozók hatására az előés utóvizsgálatok eredményeire, a vizsgálati változók korrelációjára. A tanulmányban vizsgáljuk, hogy a kognitív képességek hatékony fejlesztése miként valósulhat meg informatikai környezetben a fejlesztés hatására, a kísérleti csoport tanulóinak képességei hogyan változnak a kontrollcsoportéhoz képest, s léteznek-e nemek közötti különbségek. Vizsgálatunk kiterjed a kísérleti csoport tanulóira nézve az elő- és utóvizsgálat képességszintjére. Továbbá vizsgáljuk a kísérleti csoport tanulási motivációjának, tanulási orientációjának és kreativitásának a fejlődését.

\section{Módszer}

A négy évig tartó longitudinális vizsgálat keretében öt alkalommal történt adatfelvétel a vizsgálati ( $n=174$, fiú: 89 , lány: 85) és kontrollcsoporttal ( $n=174$, fiú: 91, lány: 83). Az első mérés 5. osztály szeptemberében történt, a további négy mérésre 5., 6., 7. és 8. osztály végén, májusban került sor. A kutatásban sor került a tanulók figyelmének, az emlékezetének, a gondolkodásának, a tanulási motivációjának, a tanulási orientációjának, a kreativitásnak, az informatikai érdeklődésének és intelligenciájának mérésére.

A kutatásban részt vevő iskolák kísérleti csoportjaiban tanuló diákok az első vizsgálat elvégzése után 4 éven (5-8. osztály) keresztül informatika alapú képességfejlesztésben vettek részt, aminek intenzitása 1 óra/hét volt. A helyszín: az iskolai számítógépterem volt. Így a képességfejlesztő foglalkozások alatt minden esetben rendelkezésére állt a tanulói számítógép, tanárgép, projektor, interaktív tábla. A program során sokféle szoftvert alkalmaztunk. A kognitív képességek fejlesztését segítette többek között, az internet sokoldalú felhasználása (böngészők); multimédiás, interaktív lehetőségek (kép, film, hangszerkesztők, táblaszoftverek); oktatócsomagok; egyéb felhasználói programok (Office, rajzoló, rejtvénykészítő, képregénykészítő, gondolattérképkészítő programok). A fejlesztés tantárgyi blokkokhoz kapcsolódott: matematika, magyar, természetismeret, történelem. A vizsgálat során fejlesztett területek a következőek voltak: figyelem (mennyiség, minőség); emlékezet (vizuális, verbális); gondolkodás (matematika logika, vizuális problémamegoldás).

\section{Eszköz}

A figyelem, az emlékezet, a gondolkodás vizsgálatára a hazai képességvizsgáló kutatásokban alkalmazott vizsgáló eljárásokat választottunk. A tesztek kiválasztását a hazai vizsgálatokban való ered- 
ményes alkalmazásuk indokolta (Balogh, 2004). A figyelem mérésére a Bourdonpróbát alkalmaztuk (Szilágyi, 1987). Az emlékezetet két teszttel vizsgáltuk, az egyik a verbális, a másik a vizuális memóriát vizsgálta. A verbális memória tesztje huszonöt szóból áll. Ezek háromszor történő elolvasása után, a tanulóknak emlékezetből 3 perc alatt le kell írniuk azokat a szavakat, amelyekre emlékeznek (Ádám és társai, 1990). A vizuális memória vizsgálata alakzatokra való emlékezés és formafelismerés segítségével történt. A tesztben kilenc ábrát kellett megjegyezniük a tanulóknak, majd egy perc alatt emlékezetből kiválasztani a másik lapon húsz ábrából azokat, melyekre emlékeznek (Kósáné, 1988).

A problémamegoldó gondolkodás vizsgálata két teszttel történt, amelyek a szabályszerűség felismerésén alapultak. A matematika logika tesztje a Meili-féle számsorok, ahol húsz számsorozatnak a szabályát kellett a tanulóknak felismerni, majd a következő két tagját a vizsgálati papírra leírni (Kósáné, 1988). Vizuális problémamegoldás tesztelése ábrasor segítségével történt, mellyel a szabályszerűség felismerését, fejlettségét mértük (Kósáné, 1988).

$\mathrm{Az}$ általános intelligencia vizsgálatára a Raven Progresszív Mátrixok intelligencia tesztet (SPM) használtuk (Raven, 1954, Kulcsár, 1982). Az iskolai/tanulási motiváció és tanulási orientáció mérésére Kozéki-Entwistle (1986) kérdőívet alkal- maztuk. A kreativitás vizsgálatára a TKBS kérdőívet használtuk (Tóth, Király, 2006).

Informatikával kapcsolatos érdeklődés vizsgálatára saját készítésű kérdőívet használtunk, melynek kérdései arra vonatkoztak, hogy a tanulók milyen viszonyban vannak az informatikai eszközökkel, lehetőségekkel, hogy milyen szívesen tanulnak a számítógép segítségével. Tizenöt kérdést, öt fokozatú skálán (5. nagyon jellemző, 1. nem jellemző) kellett értékelniük a tanulóknak. A kérdőív még négy zártkérdést és három nyitott kérdést is tartalmazott, melyek az informatikai ismeretükkel voltak kapcsolatosak.

A változók eloszlását KolmogorovSmirnov próbával, a szórás homogenitást Levene teszttel ellenőriztük, és ezek függvényében alkalmaztunk paraméteres statisztikai próbákat. A figyelem, az emlékezet, a gondolkodás méréséhez használt tesztek \%-os teljesítményértékei (helyes válaszok aránya) és annak statisztikai eredményei (leíró statisztikák, több szempontú variancaanalízis, post hoc tesztek, kétmintás t-próba, páros tpróba, korreláció) számításához SPSS programot használtunk.

\section{Kérdések és hipotézisek}

Jelen vizsgálatban az alábbi kérdések illetve hipotézisiek megválaszolása és ellenôrzése áll fókuszban:

1. kérdés: Jelentős különbség tapasztalható-e az informatikai lehetőségekkel 
fejlesztett illetve nem fejlesztett tanulók között a fejlesztést követően? Feltételezzük, hogy a fejlesztés követően szignifikáns különbséget tapasztalunk a kísérleti és a kontrollcsoport vizsgálati eredményei (figyelem, emlékezet, gondolkodás) között. Az elővizsgálatkor a vizsgálati és kontroll csoport között nincs jelentős különbség a vizsgálati változók (figyelem, emlékezet, gondolkodás) terén, és az idő függvényében. A fejlesztés hatására a kísérleti csoport tanulóinak a képességei egyenletesebben, intenzívebben, jobban fejlődnek, mint a kontrollcsoporté.

\section{2. kérdés: Különbség található-e a nemek} között a figyelembeli, az emlékezetbeli és a gondolkodásbeli teljesítményekben az informatikai lehetőségekkel történő fejlesztése során? Igaz-e például, hogy a fiúk fejlődése intenzívebb az informatikai környezet miatt, mint a lányoké? Feltételezzük, hogy a nemek (fiú, lány) között nincs jelentős különbség a vizsgálati változók (figyelem, emlékezet, gondolkodás) tekintetében a longitudinális vizsgálat alatt.

3. kérdés: Az elővizsgálatban mutatott képességszint együtt jár-e a kimeneti vizsgálatban mért eredményekkel? Feltételezzük, hogy a képességvizsgálatokban a bementi méréskor magasabb pontszámot elérő tanulók a kimeneti mérés alkalmával is magasabb pontszámot szereznek, s ez a pontszámaik erôs korrelációjában is megmutatkozik.
4. kérdés: Az olyan háttértényezők, mint a tanulási motiváció, orientáció, kreativitás szignifikáns pozitív fejlődést mutatnak-e a vizsgálat során az informatikai környezet hatására? Feltételezzük, hogy a kísérleti csoport tanulóinál a háttértényezők (tanulási motiváció, orientáció, kreativitás) is pozitív irányú szignifikáns fejlődést mutatnak a vizsgálat alatt. A folyamatos képességfejlesztés hatására pozitívabb lesz a változás, mint a kontrollcsoportnál.

\section{A kutatás eredményei}

Az. kérdés, illetve bipotézis vonatkozásában szignifikáns különbséget tapasztalunk a kísérleti és a kontrollcsoport vizsgálati eredményei (figyelem, emlékezet, gondolkodás) között a fejlesztés követően. A hipotézis igazolódott.

A kísérleti csoport és a kontrollcsoport viszonylatában a kísérleti csoport tesztekben nyújtott teljesítményei szignifikánsan jobbak voltak a kontrollcsoporténál az idő előrehaladásával. A kísérleti csoport tanúlóinak emlékezete, figyelme, gondolkodása a fejlesztés hatására folyamatosan javult. A kísérleti csoport tanulói a figyelem, az emlékezet, a gondolkodás területén nagyobb mértékű, intenzívebb, egyenletesebb fejlődést mutattak, mint a kontrollcsoport tanulói. A kontrollcsoport eredményei a vizsgálati mutatóban alulmaradtak a kísérletben résztvevőkénél. A vizsgálat során a csoport és a mérések között szignifikáns különbség $(\mathrm{p}<0,05)$ 
van, interakció figyelhető meg. A kísérleti csoportban a tanulók figyelmének a minősége kiegyensúlyozott a mérés alkalmakor, kisebb mértékű fejlődést mutat, mint a figyelem mennyiségének változása. A verbális memóriánál a vizuális memória nagyobb mértékú pozitív irányú fejlődést mutat. A legintenzívebb fejlődés a gondolkodás területén tapasztalható, ahol mind a matematika-logika mind a vizuális problémamegoldás eredményei erőteljes fejlődést mutatnak. Mindebből arra lehet következtetni, hogy a számítógépes lehetőségek és módszerek alkalmazásával hatékonyan és sikeresen lehet fejleszteni a gyermekek kognitív képességeit.

\section{A második kérdést, illetve hipotézist tekintve} eredményeink szerint a nemek (fiú, lány) között nincs jelentős különbség a vizsgálati változók (figyelem, emlékezet, gondolkodás) tekintetében a longitudinális vizsgálat alatt. A hipotézis beigazolódott.

A fejlesztés során a feladatmegoldás pontosságában nincs eltérés a fiúk és a lányok között, és a mérések során nincs szignifikáns különbség a nemek között ( $>>0,05)$ egyik csoportban sem. A vizuális problémamegoldás területén 7 . osztályban a fiúk kicsit intenzívebben fejlődtek, mint a lányok, de ennek nagysága nem jelentős.

A harmadik kérdés és hipotézis esetében azt tapasztaltuk, hogy a képességvizsgálatokban a bementi méréskor magasabb pontszámot elérô tanulók a kimeneti mérés alkalmával is magasabb pontszámot szereznek, s ez a pontszámaik erôs korrelációjában is megmutatkozik. A hipotézis tehát megerősítést nyert.

A kísérleti csoportban, az elővizsgálatban mutatott teljes figyelem, teljes emlékezet, teljes gondolkodás területén mért képességszint pontszámai és az utóvizsgálatban mért képességszint pontszámai között erős korreláció, van (a figyelemnél $\mathrm{r}=0,914$, a gondolkodásnál $\mathrm{r}=0,810$, a memóriánál $r=0,758) . A z$ erős pozitív korreláció arra utal, hogy a jobb képességú tanulók nagyobb fejlődést mutatnak, mint a gyengébb képességűek. A kezdeti előnyök megjelennek a fejleszthetőség tekintetében. A bementi méréskor magasabb pontszámot elérő tanulók a kimeneti mérés alkalmával is magasabb pontszámot szereztek A figyelem minőségénél $(\mathrm{r}=0,564)$ és a vizuális problémamegoldás ( $\mathrm{r}=0,648)$ esetében gyengébb, mérsékeltebb a korreláció a többihez képest. A figyelem minőségnél, a vizuális problémamegoldásnál a gyengébb tanulók általában a vizsgálat végénél közelítettek a 100\%-hoz, a jobbak viszont már 7. osztály végén elérték ezt a szintet.

Végül, a negyedik kérdés ésé hipotzis kapcsán az eredmények szerint a kísérleti csoport tanulóinál a háttértényezők (tanulási motiváció, orientáció, kreativitás) is pozitív irányú szignifikáns fejlődést mutatnak a vizsgálat alatt. A folyamatos képességfejlesztés hatására pozitívabb lesz a változás, mint a kontrollcsoportnál. A hipotézis részben nyert alátámasztást. 
A tanulási motiváció esetében a legnagyobb változás az érdeklődő és a teljesítő dimenzióknál volt. Az érdeklődő dimenzió esetében a két csoport között a vizsgálat végén szignifikáns különbség volt. A tanulási orientáció esetében a kísérleti csoportnál a mélyrehatoló és a szervezett dimenzió esetében szignifikáns volt a változás, nagyobb mértékű, mint a kontrollcsoportnál. A fejlesztés végén leginkább jellemző a tanulók orientációjára a megértésre, az új anyag kapcsolására, önálló kritikai véleményre, az összefüggések átlátására való törekvés. A kreativitásnál a vizsgálat végére a kísérleti csoport szignifikánsan jobb volt a kontrollcsoportnál nonkonformitás, komplexitás-preferencia, önálló gondolkodás, türelmetlenség, dominancia, kíváncsiság-érdeklődés, energikusság, játékosság-humor terén. A legnagyobb mértékű változás a türelmetlenségnél, a komplexitás-preferenciánál volt látható a kísérleti csoportban. A türelmetlenség mind a fiúkra mind a lányokra jellemző mértékben nőtt, azaz a belsőleg vezérelt motivációjuk magas. A komplexitás azt jelenti, hogy a tanulók törekszenek az újszerű, megszokottól eltérő ingerek befogadására, a bonyolultabb problémák és az ebben rejlő kihívások megoldására.

\section{Összefoglalás}

A vizsgálatok alátámasztották az informatikai képességfejlesztés létjogosultságát, így a módszer használhatóságát is:
- Szignifikáns különbség van a kísérleti és a kontrollcsoport vizsgálati eredményei (figyelem, emlékezet, gondolkodás) között a fejlesztést követően. A kísérleti csoport tanulóinak a tesztekben nyújtott teljesítményei szignifikánsan jobbak, mint a kontrollcsoporté a mérési eredmények sorrendjében.

- A kísérleti csoportban a tanulók figyelmének a minősége kiegyensúlyozott a mérések alkalmakor, kisebb mértékű fejlődést mutat, mint a figyelem mennyiségének változása.

- A verbális memóriánál a vizuális memória nagyobb mértékű pozitív irányú fejlődést mutat.

- A legintenzívebb fejlődés a gondolkodás területén tapasztalható, mind a matematika-logikánál mind a vizuális problémamegoldásnál.

- A nemek (fiú, lány) között nincs szignifikáns különbség a vizsgálati változók (figyelem, emlékezet, gondolkodás) tekintetében a longitudinális vizsgálat alatt. A fejlesztés során nincs eltérés a feladatmegoldás pontosságában a fiúk és a lányok között A vizuális problémamegoldás területén 7. osztályban a fiúk kicsit intenzívebben fejlődtek, mint a lányok, de nincs szignifikáns különbség.

- A jobb képességű tanulók jobban fejlődnek a vizsgálat alatt, mint a gyengébb képességűek. A bementi méréskor magasabb pontszámot elé- 
rő tanulók a kimeneti mérés alkalmával is magasabb pontszámot szereztek. A kezdeti előnyök megjelennek a fejleszthetőség tekintetében, leginkább az emlékezetnél, a matematika logikánál, a figyelem mennyiségénél.

- A tanulási motiváció esetében a legnagyobb változás az érdeklődő és a teljesítő dimenzióknál volt. Az érdeklődő dimenzió esetében a két csoport (fejlesztő, kontroll) között a vizsgálat végén szignifikáns különbség volt.

- A fejlesztés végén leginkább jellemző a tanulók orientációjára a megértésre, az új anyag kapcsolására, önálló kritikai véleményre, az összefüggések átlátására való törekvés.

- A kreativitásnál a vizsgálat végére a kísérleti csoport szignifikánsan jobb volta kontrollcsoportnál nonkonformitás, komplexitás-preferencia, önálló gondolkodás, türelmetlenség, dominancia, kíváncsiság-érdeklődés, energikusság, játékosság-humor terén. A legnagyobb mértékű változás a türelmetlenségnél, a komplexitáspreferenciánál látható a kísérleti csoportban.

A kutatás gyakorlati jelentősége, hogy sor került egy négy évet átfogó fejlesztő módszer kidolgozására, kipróbálására, s az eredményesnek bizonyult. A módszer alkalmazható lehet a tehetséggondozásban, illetve a különleges bánásmódot igénylő tanulók csoportjaiban is. További kutatási lehetőséget jelenthet a módszer középiskolában történő kipróbálása, ahol már megjelenik a szakképzés, illetve a magasabb szintű informatikai tudás, ezáltal a fejlesztést fókuszálni lehetne azokra a tantárgyi kapcsolódásokra, melyek a diákok érdeklődésének, továbbtanulásának középpontjában állnak. Továbbá az informatikai lehetőségek, eszközök folyamatos fejlődése lehetőséget ad a módszer „eszköztárának” folyamatos megújítására.

\section{Irodalom}

Ádám P., Balogh L., Miláth L-né és Nádudvari I-né (1990). Általános pszichológia. Tankönyvkiadó, Budapest.

Adams, A. M. és Gathercole, S. E. (2000): Limitations in working memory: Implications for language development. International Journal of Language and Communation Disorders, 35. sz. 95-117. doi: 10.1080/136828200247278

Atkinson, R. L., Atkinson, R. C., Smits, E. E., Bem, D. J.és Nolen-Hoeksema, S. (2001). Pszichológia. Osiris Tankönyvkiadó, Budapest.

$\mathrm{Az}$ Európai Parlament és a Tanács ajánlása (2006) az egész életen át tartó tanuláshoz szükeséges kulcskompetenciákrol. 2006/962 /EK (Hivatalos Lap L 394., 2006.12.30. http://eur-lex.europa.eu/ legal-content/HU/TXT/ ?uri=celex:32006H0962, megtekintve: 2014. 11. 02.) 
Balogh L. (2004). Iskolai tehetséggondozás. Kossuth Egyetem Kiadó, Debrecen.

Balogh L. (2006). Pedagógia pszichológia az iskolai gyakorlatban. Urbis Könyvkiadó, Budapest.

Báthory Z. (2000). Tanulók iskolák különbségek, Egy differenciális tanitáselmélet vázlata, Okker Oktatási Kiadó, Budapest

Case, R. (1985). Intellectual Development: A Systematic Reinterpretation. New York: Academic Press.

Cattell, R. B. (1971). Abilities: Their Structure, Growth and Action. Boston: Houghton Mifflin.

Charniak, E., McDermott, D. (1985). Introduction to Artificial Intelligencce, Addison-Wesley, Reading, Massachusetts.

Chase, W. G., Simon, H. A. (1973). The mind's eye in chess. In W. G. Chase (Ed.): Visual Information Processing. New York: Academic Press.

Chi, M. (1978). Knowledge structures and memory development. In R. S. Siegler (Ed.): Children's Thinking: what Develops? Hillsdale, NJ: Erlbaum.

Craik, K. J., W. (1943). The Nature of Explanation, Cambridge University Press, Cambridge

Csapó B. (2003): A képességek fejlódése és iskolai fejlesztése. Akadémiai Kiadó, Budapest.

Csapó B., Korom E., Molnár Gy. (szerk. 2015). A természettudományos tudás online diagnosztikus értékeléséek tartalmi keretei.
Oktatáskutató és Fejelsztő Inntézet, Budapest.

Dávid M, Dorner L, Hatvani A, Soltész P, Taskó T, Soltész-Várhelyi K. (2016): Az IKT hatása a kognitív működésekre iskoláskorban. Magyar Pszichológiai Szemle, 2016, 71. 1/9. 165195.

Dávid M., Estefánné Varga M., Hatvani A., Taskó T., Doner L. és Soltész, P. (2014). Az infokommunikációs eszközök gyakori használatának hatása a tanulói képességekre. In Bárdos J., Kis-Tóth L., Racsko R. (szerk.). Változó életformák, régi és új tanulási környezetek. Líceum Kiadó, Eger. 6376.

Debreczeni D. G. (2013): Tartalomfüggetlen online számítógépes játékok induktív és deduktív gondolkodást fejlesztő hatásának vizsgálata. XI. Pedagógiai Értékelési Konferencia, Szeged, 2013. április 11-13. 127. o.

Erikson, E. H. (1963). Childhood and Society. second ed. New York: W.W. Norton.

Estefánné Varga M., Dávid M., Hatvani A., Héjja-Nagy K. és Taskó T. (2008). Pszichológia elméleti alapok, Eszterházy Károly Főiskola, Eger. (http://www.ektf.hu/hefoppalyazat/p szielmal/index.html, megtekintve: 2014.06.27.)

Farkas K. (2000). A Játékos Informatika hatékonyságának igazolása. Új Pedagógiai Szemle. , I. évf. 11, 55-59. 
Fehérvári A., Liskó I. (2006). Az. Arany János Program Hatásvizsgálata. Felsőoktatási Kutatóintézet, Budapest

Freud, S. (1933, 1964): New Introductory Lectures on Psychoanalysis (J. Strachey, Ed. and Trans.). New York: Norton.

Galton, F. (1869). Hereditary Genius. London: MacMillian.

Gardner, H. (1983, 1986). Frames of mind: The theory of multiple intelligences. Basic Books, New York

Greenfield, P. (2009): Technology and informal education: What is taught, what is learned. Science, 323, 68-71. doi: $\underline{10.1126 / \text { science } 1167190}$

Guilford, P. J. (1959). The three faces of intellect. American Psychologist, 5, 444454.

doi:

https://doi.org/10.1037/h0046827

Gyarmathy É. (2009). Kognitív Profil teszt. Iskolakultúra. 2009/ 3-4. 60-73.

Habók A. (2011). A tanulás tanulásának vizsgálata általános iskolások körében. Magyar Pedagógia,111.(3). 207-224.

Haugeland, J. (1985). Artificial Intelligence: The Very Idea, MIT Press, Cambridge, Massachusetts.

Hautamäki, J., Arinen, P., Eronen, S., Hautamäki, A., Kupiainen, S., Lindblom, B., Niemivirta, M., Pakaslahti, L., Rantanen, P. és Scheinin, P. (2002): Assessing, learning to learn, A framework. Helsinki University in collaboration with the National Board of University in Finland, Helsinki, Finland.
Hebb, D. O. (1975). A psæichológia alapkérdései. Gondolat, Budapest

Hebb, D. O. (1997). A pszichológia alapkérdései, Gondolat-Trivium, Budapest

Hoskins, B., Fredriksson, U. (2008): Learning to learn: What is it and can it be measured? European Communities, Italy.

Janacsek K., Tánczos T., Mészáros T., és Németh D. (2009). A munkamemória új magyar nyelvú neuropszichológiai mérōeljárása: a hallási mondatterjedelem teszt (HTM). Magyar Pszichológiai Szemle, 64. (2.) 385-406. doi: https://doi.org/10.1556/MPSzle.64.2 $\underline{009.2 .5}$

Katona, N. (2000). A Woodcock-Johnson Kognitiv képességvizsgáló eljárás nemzetközi változatának magyarországi adaptálása. Előadás. Magyar Pszichológiai Társaság XIV. Pszichológia Nagygyűlése, Absztrakt kötet. Budapest, 2000. május 30.-június 2., 256.

Keil, F. C. (1989). Concepts, Kinds, and Cognitive Development. Cambridge, MA: MIT Press.

Kelemen L. (2014). A kognitív képességek rendszere és fejlődési szintjei a kultúrtechnikák elsajátítása aspektusában. In: Tánczos J. (szerk.): Fejlesz̧tó pedagógiai és pszichológiai tanulmányok I. Debreceni Egyetemi Kiadó, Debrecen. 45-60. 
Kim, K. H., Cramond, B., VanTasselBaska, J. (2010). The relationship between creativity and intelligence. In: J. C. Kaufman, R. J. Sternberg (eds.). Cambridge handbook of creativity. Cambridge University Press. New York. 395-412.

Klahr, D. (1982). Nonmonotone assessment of monotone development: An information processing analysis. In S. Strauss (Ed.): U-Shaped Behavioral Growth. New York: Academic Press.

Knausz, I. (2001). A tanitás mestersége. Soros Alapítvány támogatásával, Miskolc, (http://mek.oszk.hu/01800/01817/0 1817.pdf, megtekintve: 2013. 08.12.)

Kohlberg, L. (1976). Moral stages and moralization: The cognitivedevelopmental approach". In T. Lickona. Moral Development and Behavior: Theory, Research and Social Issues. Holt, NY: Rinehart and Winston

Kósáné Ormos V. (1988): Fejlódéslélektani gyakorlatok I., Feladatok. Tankönyvkiadó, Budapest.

Kozéki B., Entwistle, N. J. (1986): Tanulási motivádiók és orientációk vizsgálata magyar és skót iskoláskorúak körében. Pszichológia 6. (2), 271-292.

Kulcsár, T. (1982). Az iskolai teljesitmény pszichológiai tényezói. Tankönyvkiadó, Budapest

Luger, G. F., Stubblefield, W. A. (1993). Artificial Intelligence: Structures and Strategies for Complex Problem Solving
(Second edition), Benamin/Commings, Redwood City, California

Manches, A., O’Malley, C., Benford, S. (2010): The role of physical representations in solving number problems: A comparison of young children's use of physical and virtual materials. Computers \& Education, 54. 622-640. doi: 10.1016/j.compedu.2009.09.023

Mandler, J. (1983). Representation. In P. H. Mussen (Ed.): Handbook of Child Psychology (Vol. 3). New York: Wiley.

Mező F. (2011). Tanulás: diagnosztika és fejlesztés az IPOO modell alapján. $\mathrm{K}+\mathrm{F}$ Stúdió Kft. Debrecen.

Mező F. (2017). Fejlesżtō pedagógia - elmélet és gyakorlati példatár a képességfejlesztés köréböl. Kocka Kör, Debrecen.

Mező F. (2019): S.M.ART - kisiskolások kognitív képességeinek feltérképezése művészeti tevékenységbe ágyazott módon. OxIPO - interdiszciplináris tudományos folyóirat, 2019/4, 39-49. doi: 10.35405/OXIPO.2019.4.39

Mező K., Mező F. (2014): The IPOOmodel of creative learning and the students' information processing characteristics. Horizons of Psychology, 23. 136-144. doi: $10.20419 / 2014.23 .414$

Mohai K., Szabó Cs. (2014). A munkamemória vizsgálata. Gyógypedagógiai Szemle, 62. 226-232.

Molnár Gy. (2013). Mindennapi helyzetekben 
problémamegoldó

Iskolakultúra, 2013/7-8, 31-43.

Molnár Gy., Csapó B. (2011): Az 1-11 évfolyamot átfogó induktív gondolkodás kompetenciaskála készítése a valószínűségi tesztelmélet alkalmazásával, Magyar Pedagógia, 111. évf. 2. szám 127-140.

Nemzeti Köznevelés: 2011. évi CXC Törvény a Nemzeti Köznevelésröl (http://net.jogtar.hu/jr/gen/hjegy_do c.coi?docid=A1100190.TV, megtekintve: 2015.09.08.)

Newell, A., Shaw, J. C. és Simon, H. A (1958). Elements of a theory of human problem solving. Psychological Review, 65, 151-166. doi: $\underline{10.1037 / \mathrm{h} 0048495}$

Newell, A., Simon, H. A. (1961). GPS, a program taht simulates human thought. In Billing, H., (Ed.), Lernende Automaten, 109-124.p. R. Oldenbourg, Munich, Germany, Reprinted in Feigenbaum and Feldman, 1963, $207-$ 293

Ostorics L. (2015): A PIS A és az Orsquágos kompetenciamérés tanulságai, Oktatási esélyegyenlőség - Magyarország 2015, (http://www.oktatas.hu/kozneveles/ mrsek/aktualis_informaciok/pisa_ok m_tanulsagai, megtekintve: 2015. 10.25.)

Pásztor A., Molnár Gy. (2015): Induktív gondolkodás technológia alapú mérésének lehetőségei az iskola kezdő szakaszában. XV. Orsqágos
Neveléstudományi Konferencia, Budapest. 2015. november 19-21. 205.

Piaget, J. (1950). The psychology of intelligence. Harcourt Brace. New York.

Piaget, J. (1969). Az értelmi múveletek és fejlődésük. In. Válogatott tanulmányok, Gondolat, Budapest.

Piaget, K., Inhelder, B. (1969). The Psychology of the Child. New York: Basic Books

Polonkai M. (szerk.) (2004). Az. Arany János Tehetséggondozó Programban rész̧tvevó intézmények beszámolóinak összefoglalója. Arany János Tehetséggondozó Program Intézményeinek Egyesülete, Budapest

Raven, J. C. (1954): Standard Progressive Matrices (Raven progressziv mátrixok), O.S Organizationi Speciali (http://www.oshungary.hu/hu/tesztk atalogus-oshungary/raven-

progressziv-matrixok/ , megtekintve: 2008. 12.12.)

Russel, S. J., Norving, P. (2000). Mesterséges intelligencia modern megközelitésben, Panem-Prentice-Hall, Budapest

Shaffer, D. W., Squire, K. R., Halverson, R.,. Gee, J. P. (2004): Video games and the future of learning. University of Wisconsin-Madison and Academic Advanced Distributed Learning CoLaboratory (http://www.academiccolab.org/reso urces/gappspaper1.pdf megtekintve: 2016. 12. 03.) 
Sparrow, B., Liu, J. és Wegner, D. M. (2011). Google Effects on Memory: Cognitive Consequences of Having Information at Our Fingertips. Science, 333, 776-778 doi: 10.1126/science. 1207745

Spearman, C. (1904). General Intelligence, Objectively Determined and Measured. American Journal of Psychology, 15, 201-293. doi: $10.2307 / 1412107$

Spearman, C. (1927): The abilities of man. MacMillan, London.

Sternberg, R. J. (1985). Beyond IQ: A Triarchic Theory of Intelligence. Cambridge University Press, Cambridge.

Sung, Y-T., Chang, K-E. és Lee, M-D. (2008): Designing multimedia games for young children's taxonomic concept development. Computers and Education, 50. 3. sz. 1037-1051 doi: 10.1016/i.compedu.2006.07.011

Szilágyi K. (1987): A Brickenkamp: d2 (Figyelemvizsgáló eljárás). Munkaügyi Kutatóintézet, Budapest

Tánczos, T., Janacsek és K., Németh, D. (2014): A munkamemória és végrehajtó funkciók kapcsolata az iskolai teljesítménnyel. Alkalmaẓott Pszichológia, 14 (2), 55-75.

Tari A. (2011): Z generáció, Tericum Kiadó, Budapest

Thurstone, L. L. (1938). Primer Mental Abilities. Chicago: University of Chicago Press.
Tóth L, Király Z., (2006): Új módszer a kreativitás megállapítására: a Tóth-féle kreativitás becslő skála (TKBS). Magyar Pedagógia, 106. (4), 292-295.

Tóth L. (2010). Kompetencia alapú oktatás. Segédlet a kompetencia alapú pedagógusképzés módszertani megújulásához. Készült a támop-4.1.2/b projekt keretében a Győr-Moson-Sopron megyei pedagógiai intézet közremúködésével Web:

http://pszk.nyme.hu/tamop412b/ko mpetencia_alapu_pedagogia/index.ht ml megtekintve: 2014. 05.12.

Turing, A. M. (1950). Computing machineryy and intelligence, Mind, 59., 443-460. doi: $10.1093 / \mathrm{mind} / \mathrm{LIX} .236 .433$

Turner, Johanna (1994). Az értelmi fejlődés elméleti megközelítései. In: Bíró Antalné. Pszichológiától-pedagógiáig I. rész, Alextypo, Budapest, 115-127.

Vári P. (szerk) (1997). MONITOR '95 A tanulók tudásának felmérése. OKI, Budapest.

Vernon, P. E. (1950). The structure of buman abilities. London: Methuen. Yang,Y.-T. C. (2012): Building virtual cities, inspiring intelligent citizens: Digital games for developing students' problem solving and learning motivation. Computers \& Education, 59. 2. sz. 365-377. doi:10.1016/j.compedu.2012.01.012 